\title{
Islamic Education for Early Age Children: An Effort to Overcome the Negative Impacts of Industrial Era 4.0
}

\author{
Y Haryawati ${ }^{1}$, C Rakhmat ${ }^{2}$ \\ Sekolah Tinggi Agama Islam (STAI) Al-Musaddadiyah Garut ${ }^{1}$ \\ Universitas Pendidikan Indonesia (UPI) Setiabudi, Bandung 1,2
}

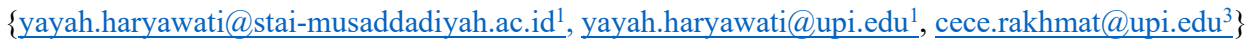

\begin{abstract}
In Islam, child education is critical to print children's personality and morality. Children, as the future assets of the nation need to be exposed to a variety of experiences that will later be useful for their lives. Industrial era 4.0 or the so called the era of disruption is the social phenomenon in which activities that were initially carried out in the real world are now shifted into cyberspace. One of the impacts on early childhood is playing solitary games using gadgets, which its excessive use will likely result in the degradation of social, moral and religious values. The 2015 research found that $80 \%$ of children use gadgets as a playground, $23 \%$ of parents who have children aged $0-5$ years claim that their children like to use the internet, while $82 \%$ of parents report that their toddlers are online at least once a week. In the next 2016 study, $94 \%$ stated that their children used to play games. Most $63 \%$ of children spend a maximum of 30 minutes playing a game once, while $15 \%$ of respondents state that children play games for 30 to 60 minutes, and the rest can interact with a game for more than an hour. This paper examines what actions do teachers and parents can do to overcome the adverse effects of playing gadgets in early childhood? This research uses the descriptive-analytical method with deductive and inductive techniques. Focusing on the types of ethnic games that exist in the Sundanese tatar, such as boy-boyan, This study found that tradional games may provide alternative solutions to deal with this game addict among the early age children.
\end{abstract}

Keywords: Islamic Education, Early Childhood, Industrial Era

\section{Introduction}

Fauzan and Fitria (2018) mentioned that in Indonesia the use of the internet is recorded so rapidly, from children to elderly, urban to rural, students to workers, all of them can easily access various information. In fact, Internet World Stats recorded that Indonesia was ranked 5th in the world in internet usage with 132.7 million users in 2017, exceeding the number of users from developed countries in the world, such as Japan (6th), Russia (7th), Germany (9th), even the UK (12th) with no more than half the number of internet users in Indonesia. The Ministry of Communication and Information Technology noted that in 2018, there would be 3.6 billion people on earth accessing the internet on their websites. In Indonesia alone, the number of internet users will reach around $51 \%$ or half more than the population.

The development of the internet and massive digital technology has become the mainstay of the movement of human and machine connectivity. Information technology is the basis of human life in the era of the fourth world industrial revolution. The development of the internet and digital technology has disrupted various human activities, including in the fields of science and technology and early childhood education.

The rapid development of the internet and technology has an impact on the extensive use of digital technology resulting in changes in people's behavior in their daily activities. Examples are transportation, retail, services, and finance. The education world cannot be separated from the strong influence of this digital technology, as well as playing and learning habits in early childhood. 
Renald Kasali [1] said that disruption is translated as a harasser, a troublemaker. In the digital word, meaning is something different and disrupts the stability of businesses that do not use the internet and digital technology as added value. Disruption, as an innovation, will replace the entire old system with new ways. Disruption will replace old physical technology with digital technology that produces something wholly new and more efficient, and more useful. Alternatively, in other words, disruption changes the old way to be more contemporary, practical, simple, effective, efficient, and able to adapt to changing times.

This paper is a study on the negative impact of disruption era 4.0 on early childhood and what the parents and teacher in ethnic-based Islamic education can do to overcome it. This study aims to describe the efforts of parents or teachers to apply ethnic-based Islamic education to overcome the negative impact of disruption era 4.0 on early childhood. However, it is important first to shed light on some importan concepts used in this research.

Spiritual nature is a fundamental potential that has the opportunity to develop. However, that development will be significantly influenced by parents, such as the hadith of the Prophet, "Every human being is born in a state of nature. Then it is his parents who can direct their children, whether they become Jews, Christians or Magi" (H.R, Bukhari). The Hadith implies that parental education factors play a very decisive role in instilling religious awareness in children. In line with that expressed by Tafsir [2], to make children who are smart, healthy, and have reasonable social adjustment, the role of the family is very dominant. The family is one of the main determining factors in the development of children's personality, in addition to other factors.

The nature of the child can grow and develop following the guidance of Islam, if from the beginning the child gets the inculcation of the values of Islamic teachings, covering three main pillars consisting aqidah, shari'a, and morals. The three pillars are the basic needs of children's development: aqidah, sharia, and morality.

Early childhood can grow and develop into the next generation who behaves in a virtuous manner, if they get proper moral cultivation, both to God, to themselves and the family environment and the surrounding environment. Through practice, habituation, and exemplary examples of family members, especially parents, because what is received and experienced by children from an early age will cling to him and will shape his personality, while also using traditional play methods and media such as boys and girls.

Rhenald Kasali, in his book Disruption [1], explains that digital disruption (digital disruption) is something that comes after the digital era and disrupts the stability of businesses that do not use the internet and digital technology as added value. The term digital disruption can then be interpreted as a change that arises because of digital Technology and Digital Business Models that impact on the ups and downs of the business value of a service or goods that already existed before. Character is influenced by heredity, as stated by Samani \& Hariyanto [3] that character can be interpreted as a primary value that builds a person's personality, is formed both because of heredity and environmental influences, which distinguishes it from others, and is manifested by his attitude and behavior in daily life -day. Imam Al-Ghazali considers character closer to morals, namely human spontaneity in attitude, or doing actions that have been integrated with humans so that when they appear, they don't need to think about it anymore.

Character development for early childhood is done through habituation and core activities. Recognition through habituation is done through daily activities, such as washing hands and praying before and after eating, reflecting and putting on makeup, combing hair, and arranging clothes, cleaning and arranging classes before returning home, gardening, planting trees, and caring for animals, while also being able to do through traditional games like boy-boyan.

\section{Method}

This study uses a qualitative approach to describe the efforts of parents or teachers to apply ethnic-based Islamic education to overcome the negative impact of disruption era 4.0 on early childhood, by using descriptive and inductive analysis descriptive methods on Islamic education variables of Early Childhood and the negative impact of disruption era 4.0. 


\section{Result and Discussion}

\section{The Digital World and Early Chilhood}

Islam places great importance on children's education starting from as early as possible. Even before birth (in the womb), mothers have been encouraged to do good and enjoyable work. The goal is for children to be healthy, agile, intelligent, and resilient in facing various challenges so that they become the next generation who can carry out the tasks assigned to them.

Children in the Islamic view are sacred or natural. Fitrah means a potential that is bestowed by God directly to every newborn human child. Human beings, who are endowed with the nature of religion, with the term "homo divinans and homo religious," which is a creature of God or religion. Religious nature is a fundamental potential that has the opportunity to develop. However, that development will be significantly influenced by parents, such as the hadith of the Prophet, "Every human being is born in a state of nature. Then it is his parents who can direct their children, whether they become Jews, Christians or Magi "(H.R, Bukhari). The Hadith implies that parental education factors play a very decisive role in instilling religious awareness in children. In line with that expressed Tafsir [2], to make children who are smart, healthy, and have proper social adjustments, the role of the family is very dominant. The family is one of the main determining factors in the development of children's personality, in addition to other factors.

The meaning of fitrah in the above hadith is comprehensive and deep, and contextually the child has the potential to develop both the physical aspects of motor, language, cognitive, emotional, social, moral, and religious. Parents play a critical role in children's development, including in the emotional aspect so that children can have courageous characters or morals, be healthy, cooperate, help one another, steadfast, and others. Parents in the hadith can be interpreted comprehensively if in the family means parents are biologically and sociologically religious, while in school are teachers and in the community are parents, adults, and anyone responsible for helping children develop better.

The family, school, and community components, as well as the government, work together to carry out the right education following the stages of child development. According to Aristotle [4] the growth and development of children, divided into two phases. The first phase, from 0 to 7 years, is called childhood to playtime. The second phase, children aged 7 to 14 years, is called childhood, which is known as the period of deep learning, while Daradjat [5] argues, children aged 3-4 years are known as defiance or crisis period. In terms of education, at that time, the opportunity for disobedience was opened, as well as a foundation for upholding compliance. At that time, children are open to opportunities to accept the truth. After that, the child has an inner awareness. This is where a touch of education is needed to grow the motivation of education towards educational goals, symbolic and sub-stages of intuitive thinking. In this phase, children learn by playing.

Herbert Spencer, as a figure from the theory of playing surplus energy [6], said children play because they have excess energy. This energy encourages them to carry out activities so that they are free from feeling depressed. This means that, without playing, children will experience severe problems because their energy is not channeled. In the play, children can imagine so that they can increase children's creativity. The opportunity to think between the boundaries of the real world allows children to get to know more creative thinking processes that will be very useful in everyday life.

Game (play) is a fun activity that is carried out for the benefit of the activity itself [7]. Erikson and Freud: Games are a form of human adaptation that is very useful in helping children master anxiety and conflict. Piaget sees it play as a method that enhances children's cognitive development.

\section{Boy-Boyan: An Ethnic Based Game}

The boy-boyan is a traditional game originating from the province of West Java. In the Sundanese area of origin of this game, some call it a boy-boyan, some also call it Bebencaran. This game has a different name in each region. In Pati, it is known as Gaprek Kempung. In some other areas, the game is called Gebokan, which comes from the sound of a rubber ball that is used in the game about the limbs of the player will make a "Gebok" sound. In Padang, the game is known as Pecah Piring. This traditional game combines the motor work of the child and also hone 
the ability to make strategies. The tools used in this game are broken tiles or earthenware, broken pieces of asbestos, pieces of wood, or broken bricks, or milk cans, etc. Plastic balls, tennis balls, or make your balls from paper bundles that are wrapped crackle bags and tied with rubber. This ball is used to knock out opponents. The number of players in boy-boyan games is 8-10 players; it is cultivated an even number because each squad, both attacking squad and guard squad, are the same numbers so that the game can run in balance.

The game begins to form a defense team and an attack team by making suits, the winning team becomes the attacking team, and the loser in the suit will become a guard team. The children of the attacking team will take turns throwing the ball in the direction of the tile arrangement to collapse. When the tile arrangement was shot and collapsed, the attack team members would run away from the children of the guard team.Next, the attacking team must rearrange the scattered tile towers while avoiding ball shots from the guard. If the attacker is hit will become a defender and vice versa. Usually, the guard team will scream to pass the ball so as far as possible to shoot the ball towards the attacking team members successfully. While the attacking team will try the opposite, which is to stay away from the guard team in order to avoid being shot. The guard team tried to arrange the tile into a complete arrangement again. If a throwing ball hits no one by the guard team, and the tile arrangement is re-erected, then the game ends with a score of 1-0 for the attacking team. Then the game will be repeated like that until it can be determined. The gamewinner team.

The boy-boyan game is indeed straightforward, but behind its simplicity, the child is taught about how to work together in a team, which is trying to protect a friend from being hit by an opponent's ball. Besides that, this game also trains concentration. Concentrating when shooting the ball so that it hits the tile and can knock it down. Another lesson that can be taken from the boyboyan game is that children learn about the accuracy and speed when they have to avoid enemy ball shots and to stack the scattered tiles.

Aside from being a traditional game entertainment, boy-boy turned out to have many benefits that are needed by children. The benefits of boy-boy games can be grouped into psychomotor, cognitive, language, emotional, social, and moral religious groups.

The cognitive value contained in these boyish games is that the attacking players must think that they can rearrange the tower without being hit by the ball from the watchman group, as well as the watchman group must try to thwart the efforts made by the winning group to arrange the tower; therefore, the players must think and plan strategies well in order to become a winner.

The psychomotor aspect contained in the traditional game of boy-boyan, includes training the physical abilities of children. In this traditional game, physical motion is emphasized. Playing this game is very good for channeling excess child energy because children do have to move a lot. In this game, children are required to run actively, the winning group tries to avoid the ball being thrown by the guard group, and the guard group tries to throw the ball to hit the group of players.

The social aspect of game is that children can socialize with their friends. Traditional games allow for social interaction. Interaction in traditional games encourages children to learn about the concept of sharing, waiting their turn, playing fair, also teaches the meaning of victory and defeat. Through real contact with others, children learn to find who they are in the middle of the scope of relationships, what can be done, how he can adjust to the situation around him. Moral and religious aspects, with this game, children, will learn honesty, courage, and obedience.

\section{Conclusion}

The impact of the disruption era can be anticipated, one of which is by reviving ethnic or traditional Sundanese boy-boy games. Directing children to maintain a balance between individual and social interests. It does mean that children are prohibited from playing gadgets at all, but the duration and depth of play can be combined with traditional games so that caring characters, cooperation, enthusiasm, concentration, and so on can develop naturally.

Islam teaches humankind to be healthy and active both physically and psychologically. Education can be done through four components, namely family, school, community, and government, all of which must synergize to create harmony in early childhood development. Together facilitate to reactivate traditional games that are rich in national cultural values. 


\section{References}

[1] R. Kasali, Disruption. Jakarta: Gramedia Pustaka Utama, 2017.

[2] A. Tafsir, Cakrawala Pemikiran Pendidikan Islam. Bandung: Mimbar Pustaka, 2004.

[3] M. Samani and Hariyanto, Konsep dan Model Pendidikan Karakter. Bandung: Remaja Rosdakarya, 2013.

[4] S. Suryabrata, Psikologi pendidikan. Jakarta: PT Rajagrafindo, 2005.

[5] Z. Daradjat, Metodik khusus pengajaran agama Islam. Bandung: Bumi Aksara, 1995.

[6] C. E. Catron and J. Allen, Early Childhood Curriculum A Creative-Play Model. New Jersey: Merill, Prentice-Hall, 1999.

[7] J. W. Santrock, Life span development: Perkembangan masa hidup. Jakarta: Erlangga, 2002. 